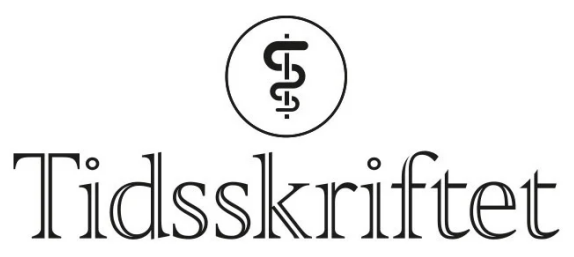

DEN NORSKE LEGEFORENING

\title{
Peter B. Kryvi
}

\author{
MINNEORD
}

LENE KVAMSDAL

\section{PAAL NYGAARD}

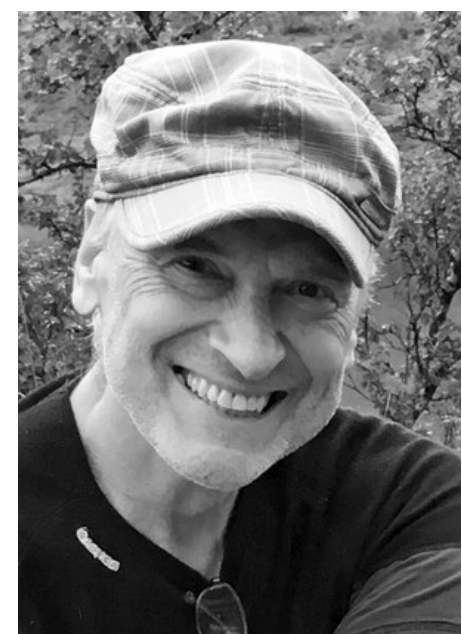

Vår gode venn og dyktige kollega Peter B. Kryvi døde brått og uventet 11.3.2021, bare 68 år gammel.

Peter ble født i Bergen 15.11.1952. Han vokste opp på Skjold som yngstemann i en søskenflokk på fem. Faren var allmennpraktiserende lege. Familiens store interesse for naturvitenskap preget oppveksten, og Peter tilbragte mye tid i skogen og på fjellet.

Etter gymnaset studerte han medisin ved Queen's University, Belfast. Han ble cand.med. i 1979. I Belfast traff han tidlig sin kjære kone Olive som studerte odontologi. Peter hadde hele livet en enorm interesse for medisinfaget. Han kastet seg over studiet med iver og iherdighet, og det ble mange sene kvelder over bøkene. Hans grundige studier ga et meget godt utgangspunkt for god legepraksis. Etter studiet tok han sykehusturnus ved Royal Victoria Hospital.

Peter flyttet tilbake til Norge i 1980 sammen med sin kone. Etter en kort tid som assisterende legevikar på Solli, ble det distriktsturnus i Tana i 1981. Fra sommeren 1981 gjennomførte han militærtjeneste som lege ved Haakonsvern. Deretter arbeidet han ved Bergen legevakt inntil han i 1984 overtok sin fars allmennmedisinske legepraksis på Nesttun. Han ble tidlig spesialist i allmennmedisin og fortsatte som fastlege inntil han pensjonerte seg i desember 2020. 
I hele yrkeskarrieren opprettholdt Peter et svært høyt faglig nivå ved oppdatering $\mathrm{i}$ nasjonale og internasjonale fagtidsskrift og regelmessig kursdeltakelse. Han organiserte og var drivkraften bak - faglig oppdatering i smågruppen.

Peter var en ekte kliniker. Med sin diagnostiske kompetanse, sine praktiske ferdigheter samt et ekte engasjement for både faget og pasienten, var han et forbilde for mange. Dette gjorde ham også til en respektert og svært avholdt lege blant pasientene, og han ble den mest $ø$ nskede fastlegen i Bergen da ordningen ble innført.

Peter hadde mange interesser og var spesielt glad i natur, musikk og trening. Han var et naturlig midtpunkt i en tett venne- og kollegagjeng. Han delte villig av sin store kunnskap om dyr og planter, men også om historie, geografi, geologi og astronomi. Ikke minst var han svært opptatt og stolt av sine tre barn. Han gledet seg stort over at de arvet hans interesse for naturvitenskap og utdannet seg som fysiker, lege og veterinær.

Vi kommer til å savne Peter, hans ivrige søken etter ny kunnskap, kjærlighet til naturen, faglige trygghet og det gode vennskapet.

Våre tanker går til hans kone Olive og deres barn Jacob, Peter Daniel og Marthe.

På vegne av kolleger og hans mange gode venner

Publisert: 25. mai 2021. Tidsskr Nor Legeforen. DOI:10.4045/tidsskr.21.0309

(C) Tidsskrift for Den norske legeforening 2023. Lastet ned fra tidsskriftet.no 26. april 2023. 